\title{
Pyhä sota ja kansalaisuskonto uudella Venäjällä
}

\author{
Kahla, Elina
}

$2020-12-30$

Kahla , E 2020 , ' Pyhä sota ja kansalaisuskonto uudella Venäjällä ' , Idäntutkimus , Vuosikerta. 2020 , Nro 3-4, Sivut 20-33 . https://doi.org/10.33345/idantutkimus.101986

http://hdl.handle.net/10138/331982

https://doi.org/10.33345/idantutkimus.101986

unspecified

acceptedVersion

Downloaded from Helda, University of Helsinki institutional repository.

This is an electronic reprint of the original article.

This reprint may differ from the original in pagination and typographic detail.

Please cite the original version. 
Pyhä sota ja kansalaisuskonto uudella Venäjällä

Pikainenkin vierailu missä tahansa Euroopan puoleisessa venäläiskaupungissa auttaa ymmärtämään, miten läsnä toisen maailmansodan muisto on. Pietari ympäristöineen ei tee poikkeusta. Jokainen koululainenkin tietää jotain Leningradin piirityksestä: osaa mainita sen alku- ja loppumispäivämäärät, Olga Berggoltzin silminnäkijän runot sekä Elämän tien eli talvisen huoltotien Laatokan jään yli. Piirityksen kokeneiden blokadnikien huomiointi muistopäivinä kuuluu asiaan. Jos silloin pistäytyy Piskarjovkan hautausmaalla, osuu keskelle rituaalia. Virallinen johto laskee graniittikiveyksille seppeleitä, omaiset asettelevat nurmelle punaisia neilikoita, kenties palan leipää ja pikarin vodkaa. Suru ja menetykset ovat menettäneet tarkat ääriviivansa. Kahdeksankymmenen vuoden takaiset kauhut ovat aikaa sitten sekoittuneet myöhempiin kauhuihin. Muistelijat ovat vaihtuneet toisiin. Nyt mummit, lettipäätytöt ja solmioon puetut pikkupojat kannattelevat tätä muistia. Silmä erottaa joukosta niin univormuja kuin siviiliasuja, niin järjestöjen lippujen kantajia kuin jokamiehiä. Mahtavuudessaan levollinen Äiti-synnyinmaa -monumentti kannattelee levitetyin käsivarsin valettua seppelettä. Matruusi ja työläinen ovat painaneet katseensa alas kohti maata. Musiikki soi vaimeana kaiuttimista. Muistopuistossa kävely, kirjoitusten ja taideteosten katselu tiivistää tänne kokoontuneet yhteen. Muurien ulkopuolella he ovat toisilleen vieraita ihmisiä, mutta tässä ja tämän hetken he ovat pyhän kosketuksen yhdistämä kansa.

Omat muistoni Piskarjovkasta ovat jo vähän himmenneet, mutta luultavasti perinne jatkuu siellä edelleen yhtä elinvoimaisena, aivan kuten muissakin vastaavissa paikoissa. Uutta on se, että näitä uusia sotasankaruudelle omistettuja paikkoja tulee koko ajan lisää. Ne ilmentävät kirkon ja puolustusvoimien yhteisiä päämääriä. Sitä, että toista maailmansotaa eli "1418 päivää ja yötä, 27 miljoonan meille rakkaan läheisen menetettyä elämää” (Mitrofan, 2020,158) ei saa unohtaa ja että hengelliseen maanpuolustukseen panostetaan laajalla rintamalla. Uusia näyttäviä pyhäköitä nousee jatkuvasti: esimerkkeinä laivaston kirkko Kronstadtissa ja voitonpäivän 75-vuotisjuhlan kunniaksi 9.5.2020 vihitty Venäjän armeijan pääpyhäkkö Moskovan liepeillä. Jälkimmäinen on saanut paljon huomiota ja ihmettelyä osakseen. Puolustusministeriön nettisivuilla sanotaan sen olevan Venäjän hengellinen symboli, joka ylistää elämän suurinta voittoa kuolemasta. Lisäksi sen motoksi on nimetty sotapäällikkö Suvorovilta lainattu lausahdus: "Rukoilkaa Jumalaa - voitto tulee Häneltä. Jumala on meidän kenraalimme, Hän johdattaa meitä” (https://hram.mil.ru). Venäjän historiaa 
laajemmin esittelevät sankarihistoriapuistot isoissa kaupungeissa edustavat nekin hengeltään tätä uutta trendiä. ${ }^{1}$

Miksi sota ja pyhyys yhdistyvät? [Esseen tavoite]

Väitän tässä kirjoituksessa, että jostain muisteluperinteen elinvoimaan liittyvästä syystä sota ja pyhyys yhdistyvät venäläisissä keskusteluissa taajaan. Vaikka pyhän sodan teema on ajaton ja kosminen eli hyvän ja pahan väliseen ikuiseen taistoon liittyvä, ja vaikka vääristelyä on harjoitettu aina, niin tematiikan suosio on viime vuosina vain voimistunut. Kysyn, miksi sodasta pitää koko ajan puhua ja mikä siinä on niin pyhää, ettei yhdenmukaista puhetta sovi kyseenalaistaa?

Käytän aineistona esimerkkejä populaareista pyhää sotaa käsittelevistä kirjoista. Sotilastaustainen Murmanskin ja Montšegorskin metropoliitta Mitrofan (Badanin) on omistanut tuoreen teoksensa "Suuren sodan salaisuus" (Tajna velikoi vojny, 2020) toisen maailmansodan historiallisiin ja hengellisiin, salattuihin merkityksiin. Tekijän aiemmat teokset ovat käsitelleet Venäjän ortodoksisen kirkon historiaa ja pyhittäjiä Kuolan niemimaalla. Hän on myös koonnut "Kursk"ydinsukellusveneen uppoamisesta kertovan muistoalbumi-kuvateoksen (Neugasimaja lampada ”Kurska" 2013). Esseeni hyödyntää näitä kahta sekä maallikko Vladimir Zobernin ”Jumala ja voitto”(Bog i pobeda, 2014) -teosta, joka suoraan käsittelee toista maailmansotaa uskonnon kannalta.

Tuoreet kyselyt paljastavat "suuren sodan" (velikaja vojna) - jolla nykypuheessa tarkoitetaan toista maailmansotaa - merkitsevän kansakunnan identiteetin kannalta suurinta yhteistä nimittäjää, jonka merkkinä voitonpäivä on yhtä tärkeä juhla kuin oma syntymäpäivä (Kangaspuro 2020). Sota kosketti kaikkia SNTL:n ja sen seuraajavaltioiden perheiden kohtaloita. Kosketus on silti kaikkea muuta kuin tarkkarajainen, saati yksiselitteinen, sillä sen mittaamattomia menetyksiä edelsi 1930luvun suuri terrori ja sen mukanaan tuoma jaottelu omiin ja kansanvihollisiin. Yksi nykytrendi onkin kansanvihollisten jälkeläisten äänen, ns. vernakulaarin esiintuominen. Moni muistelija on

\footnotetext{
1 "Venäjä - minun historiani” -historiapuistot ovat osa viime vuosien suurhanketta eli Venäjän historiaa esitteleviä näyttelykokonaisuuksia, joiden toiminta ja teemanäyttelyt ovat esillä paitsi eri kaupunkien paviljongeissa myös sähköisinä. Nettisivusto mainitsee 22 kohdetta eri puolilla Venäjä: Pjatigorsk, Volgograd, Jekaterinburg, Kazan, Krasnodar, Mahatškala, Moskova, Nižni Novgorod, Novosibirsk, Omsk, Perm, Donin Rostov, Samara, Pietari, Saratov, Stavropol, Tjumen, Ufa, Južno-Sahalinsk, Jakutsk, Tšeljabinsk, Surgut. http://myhistorypark.ru/about/. Katsottu 20.11.2020.
} 
kertonut, että perheenjäsenet saattoivat ensi kerran hengähtää helpotuksesta Hitlerin hyökkäyksen alettua: enää ei tarvinnut pelätä omia - yhtä paljon.

Toinen sodan pyhyyteen liittyvä perustelu liittyy menetysten mittakaavaan. Hitlerin sotakoneen hyökkäys 22.6.1941 toimi kuin Moolokin kita. ”Ei askeltakaan taaksepäin” -määräys suoraan Stalinilta myös takasi sen, että neuvostosotilaiden menetykset koko sodan aikana ylittivät länsiliittoutuneiden menetykset räikeän moninkertaisesti (Hosking 2006). ${ }^{2}$ Tappioista tai niiden syistä ei kuitenkaan ollut ennen perestroikaa lupaa kirjoittaa avoimesti saati kriittisesti. Luvuista kiistellään yhä. Tekstejä vertaillessa törmää säännönmukaisesti siihen, että Venäjän virallinen taho viittaa suuriin uhrauksiin samalla muistuttaen, että Neuvostoliitto pelasti "koko maailman" natsien tuholta. Yleisen venäläisen ajatuskulun mukaan silloisten liittolaisten tulisi tuntea uhrauksesta kiitollisuutta, ja omien puolestaan tyytyä viralliseen sankarikertomukseen tosiasioita liikaa pöyhimättä. Vernakulaari ääni sallitaan, mutta ei sen levittämistä maailmalle. Kaanonin kyseenalaistajat eivät saa kotimaissaan kiistatonta kiitosta, mistä Nobel-palkitut kirjailijat, viimeisimpänä Svetlana Aleksijevitš (2015), ovat tunnetuimpia esimerkkejä. Aleksijevitš on käyttänyt kollektiivista ääntä kaikissa sota-aiheisissa teoksissaan silottelematta, paljastavana ja todistusvoimaisena (esimerkiksi teoksessa Sodalla ei ole naisen kasvoja, suom. Pauli Tapio, 2017). Edelleen suurimman huomion saa osakseen venäläiskansallinen näkökulma. Vähemmistökansojen ääni ei pyhän sodan muistelmakaanoniin kuulu, vaikka poikkeuksia säännöstä olisikin.

Pyhän sodan teeman suosion kasvulle voi löytää myös ulkoisia tekijöitä. Ulkopoliittinen suhdanne on asettunut aina keväästä 2014 lähtien niin pysyvän vihamieliseksi, että Venäjän voi todella päätellä kääntäneen selkänsä lännelle ja lähentyvän systemaattisesti ennen kaikkea sotilaallisesti orientoitunutta, yhtä lailla uhrauksia kansalaisiltaan vaativaa ja yhdenmukaisuutta edellyttävää Kiinaa. Pyhän sodan oikeutuksen retoriikka sopii toiseuttavan suuntauksen mielikuvan lujittamiseen: "me" edustaa vallanpitäjien konservatiivia hegemoniaa ja uskollisuutta esi-isien perinteille ja uhrautuvaa taistelua viimeiseen veripisaraan, kun taas "ne" - rappeutunut "Gayropa" liehuttaa sateenkaarilippua, vähemmistöjen ihmisoikeuksien ja yltiöindividualismin puolesta.

Venäjä muistuttaa yhä säännöllisesti entisiä satelliittivaltioitaan historian oppitunneista, sekä siitä, mitä Hitlerin Saksan voitto olisi niille merkinnyt. Antagonistisessa retoriikassa eurooppalaiset "ystävät" varustetaan tekstissä lainausmerkein ja puheessa erityisellä äänensävyllä. Tähän liittyy oman pyhyyden manifestoinnin rinnalla vastustajan pyhän alentaminen. Gott mit uns -moton

\footnotetext{
${ }^{2}$ Geoffrey Hoskingin $(2006,242)$ mukaan kerrannaisvaikutukset, kuten syntymättä jääneet lapset mukaan lukien, SNTL:n väkiluku jäi vuosina 1939-1950 45-50 miljoonaa pienemmäksi kuin jos sotaa ei olisi käyty. Väestöryhmittäin arvioituna venäläiset, valkovenäläiset ja ukrainalaiset kärsivät lukumääräisesti eniten.
} 
venäjännös on S nami bog, jumala (pienellä kirjaimella) on kanssamme. Perivihollinen on aina sama, aikaan ja paikkaan sitomaton Antikristus, jota vastaan käydään kosmista sotaa. Tätä retoriikkaa korostetaan pontevasti 2014 jälkeisessä maailmanjärjestyksessä.

Kahtiajakoa edistävän, monen eri nimittäjän määrittelemän toimeliaisuuden alueita on paljon, ja niitä on helppo havaita ja nimetä. Venäjän alueet suorastaan kilpailevat keskenään sotamuistoturismissa. Kaikki keinot eivät kestä kriittistä tarkastelua, samoja sankarihahmoja ja tarinoita kierrätetään surutta (ks. esim. Zhurzhenko 2020). Vihollisen julmuuksien kuvauksissa todenperäisyyttä kysytään vielä vähemmän (Sartorti 1995). ${ }^{3}$ Karjalan joukkohautoja pitkään tutkineen petroskoilaisen Juri Dmitrijevin tapaus on suomalaisiakin koskettava karmea esimerkki. Juri Dmitrijev sai syyskuussa 2020 pitkän lisän vankilatuomioonsa (Palomäki 2020). Hän yritti ottaa selville, keitä ja keiden teloittamia missäkin joukkohaudassa lepää. Myötäilevä enemmistö koki sen yritykseksi loukata omaa pyhää.

Kirkon ja sekulaarin vallan, mukaan lukien puolustusvoimien ja paramilitaaristen järjestöjen (esim. kasakoiden), välisen yhteistyön tiivistyminen, on nähtävä "kulttuurisodan" toimeliaisuutena. Toimijan rooli on osunut laajalle kirjolle kirkollis-poliittisluonteisia tahoja aina vapaaajantoiminnasta kulttuurituotantoon, nuorisokasvatuksesta veteraaneihin (Afganistanin, Tšetšenian ja sen jälkeisten konfliktien veteraanit). Päivittäiskanavia ovat ko. tahojen ylläpitämät nettimediat, opetuspuheet ja julkaisutoiminta.

Pyhästä sodasta ilmestyy koko ajan runsaasti populaareja teoksia. Kuuluisin esimerkki lienee presidentti Vladimir Putinin rippi-isäksi mainitun metropoliitta Tihon Ševkunovin huippusuosittu, kolme miljoonaa kappaletta myynyt teos Arkielämän pyhiä ynnä muita kertomuksia (Nesvjatyje svjatyje i drugije rasskazy, 2011; suom. 2016), joka kertoo Petserin luostariin päätyneistä sotaveteraaneista. Lajityyppi on lähes humoristinen anekdoottikokoelma. Kertomuksissa on syvyyttä ja jännitystä, sekä maallisia kärsimyksiä että yliluonnollisia käänteitä.

Pyhän sodan retoriikalle erityisen otollisia ovat rajamaat. Pohjoisen Jäämeren rannikon ja Kuolan niemimaan geostrateginen merkitys on monista syistä kasvanut. Ns. hengellisen maanpuolustuksen merkeissä laivastotukikohdissa Severomorskissa ja Umbassa on vuodesta 2013 lähtien toiminut sotilaspiispa. ${ }^{4}$ Vuodesta 1995 toimineessa Murmanskin hiippakunnassa sijaitsee kolme luostaria. Näistä perinteisin on sotilasalueella lähellä Suomen rajaa toimiva Petsamon miesluostari, toinen

\footnotetext{
${ }^{3}$ Rosalinde Sartorti (1995) on osoittanut tutkimuksessaan kuuluisan tarinan natsien teloittamasta komsomolityttö Zoja Kosmodemjanskajasta, Neuvostoliiton sankarista, taruksi, mutta viittausta tähän tutkimukseen ei helposti löydä eikä sitä noteerata yleisesti.

${ }^{4}$ Ks. <http://www.patriarchia.ru/db/text/4831740.html>.
} 
Hiipinän naisluostari. Kolmas, Kuolan kaupungissa sijaitseva miesluostari avattiin vuonna 2019. Murmanskin kaupungin suuri katedraalihanke etenee joukkorahoituksella ${ }_{2}$ samoin maan ensimmäinen hengellisen urheilukeskuksen rakennushanke. ${ }^{5}$

Myös monet uskontotutkijat ovat kiinnittäneet huomionsa pyhän sodan teemaan. Boris Knorre ja Aleksei Zygmont ovat hiljattain monipuolisesti kommentoineet ortodoksiteologien sotaan liittyviä käsityksiä kirjoituksessaan Sotaisa hurskaus 21:lla vuosisadalla (Militant Piety 2019). Eräs uuden Venäjän ensimmäisistä oli Yleismaailmallisen venäläisen kansankokouksen (Vsemirnyi Russki Narodnyi Sobor) julkilausuma Sotapalvelun pyhyydestä (O svjatosti ratnogo služenija, 1995).

Nykykeskustelu pyhän sodan oikeuttamisesta liittyy myös venäläisen kansalaisuskonnon teoreettiseen kehykseen. Kansalaisuskonnon (civil religion) modernissa yhteiskuntatieteessä lanseerasi amerikkalainen uskontososiologi Robert N. Bellah (1967, 11-21). Hänen määritelmänsä mukaan kansalaisuskonnossa kyse on yhteisen kehyksen luomisesta, mahdollisuudesta osallistua pyhän kokemukseen, jossa Jumalan sijaan keskiössä on oman kansakunnan erityislaatu ja kohtalo. Bellah piti kansalaisuskontoa Yhdysvaltojen oloissa myönteisenä ilmiönä. Myöhemmin hän nimitti maan perustajaisää Abraham Lincolnia amerikkalaisten suurimmaksi, ja kenties ainoaksi kansalaisteologiksi (civil theologian), mutta toisaalta myönsi myös "papittoman ja kirkottoman" kansalaisuskonnon heikkoudet (Bellah \& Hammond 1980, 15).

Sittemmin kansalaisuskonnon käsitettä on sovellettu hermeneuttisena tulkinta-avaimena myös ortodoksisen uskontokunnan miljöössä. Cyril Hovorun, ukrainalaissyntyinen, Moskovan patriarkaatin sisäpiiristä ulkomaille siirtynyt teologi ja arkkimandriitta, on soveltanut käsitettä analyysissään nyky-Venäjän valtiovallan näkemyksiä myötäilevän Yleismaailmallisen venäläisen kansalliskokouksen pehmeän vaikuttamisen toiminnasta. Hovorunilla on omakohtainen kokemus tällaisen vaikuttamisen kohdistumisesta häneen itseensä. Hän erittelee venäläisen kansalaisuskonnon niin myönteisiä kuin kielteisiäkin puolia seuraavasti:

[...] käsitteen rakentava puoli on ihmisten yhdistäminen ja rakentaminen kansakunnaksi, valta mobilisoida joukkoja yli aineellista hyvinvointia ajaviin tarkoituksiin. Se voi kuitenkin myös mobilisoida massoja tukijoiksi ja osallistumaan jopa sotilaallisiin konflikteihin, syrjäyttämään ja vihaamaan "toisia”, laillistamaan

\footnotetext{
5 Katedraalihankkeesta ks. <https://sobor-murman.ru/video>; urheilukeskuksesta ks. <https://murmanmissia.ru/new/2020/11/11/10903/>.
} 
diktatuuri ja sakralisoimaan korruptio. Kansalaisuskonto uhkaa kirkkoa muuttamalla merkittävästi sen alkuperäistä luonnetta ja tarkoitusta. (Hovorun, 253, 2017.)

Hovorunin mukaan nyky-Venäjän kansalaisuskonto on kirkon hyväksymä teologian transformaatio ideologiaksi, jossa epäselvää on, yhdistääkö toimijoita jumalausko vai pikemmin vallan legitimoinnin turvaaminen ja omat uramahdollisuudet siinä sivussa. Jaan Hovorunin käsityksen, että vaikka kansalaisuskonto uhkaa kirkon auktoriteettia muuttamalla merkittävästi sen alkuperäistä luonnetta ja tarkoitusta, niin ilmiötä sinänsä ei kannata sivuuttaa. Traumaattisten muistojen kehystäminen suuremmalla pyhän sodan yhteisellä nimittäjällä on mielestäni tyypillinen venäläisen kansalaisuskonnon ilmenemismuoto. Siinä ammennetaan menetetyn keisariajan käytänteistä, osoitetaan jatkuvuuksia, valjastetaan idealisoitua historiaa nykykäyttöön ja tarpeen mukaan vahvistetaan vastakkainasettelua.

Seuraavaksi tarkastelen ensin yksityiskohtaisemmin pyhän sodan käsitettä venäläisenä kansalaisuskontona, minkä jälkeen edellä mainittujen, kirjailija-kustantaja, maallikko Vladimir Zobernin $^{6}$ sekä metropoliitta Mitrofanin (Badanin) pyhään sotaan liittyvää ajattelua.

Kansalaisuskonto ortodoksisella Venäjällä

Itä-Rooman perinnettä kantavassa ortodoksikristillisessä miljöössä, jossa traditioon sisäänrakennettuna on voimakas taipumus säilyttää ortodoksia alkuperäisenä, uudistukset herättävät epäluuloa. Uudistaminen nähdään usein alkuperäisen, täydellisen jumalallisen sanoman vastaisena, mahdollisesti vihamielisenä "latinalaistamisena", minkä estäminen on kirkon identiteetin ydintä. Vihollisen "ristiretkeläisiltä" suojautumiseen liittyy voimakas tarve kitkeä harhaoppiset pois ja puolustaa omaa yhteisöllisyyttä niin ulkoa tulevilta vihollisilta kuin omilta kapinoitsijoilta, missä kehyksessä kansalaisuskonnolle on jatkuvaa tilausta. Käsitteenä se on avara ja moniulotteinen eikä mene enemmistön kannalta liialle äärimmäisyyksiin kuten sitä radikaalimpi poliittisen uskonnon käsite.

Jos Yhdysvaltojen kansalliseksi maallikkoteologiksi sopii Abraham Lincoln, niin venäläisen kansalaisuskonnon profeetoista tärkein on slavofiili-kirjailija Fjodor Dostojevski. Kirjailijan ajattelumaailmaa lähellä on Riivaajien hahmo Šatov, jonka usko määrittyy seuraavanlaisesti:

\footnotetext{
${ }^{6}$ Vladimir Zobern (s.1949) on ortodoksisen kirjallisuuden menestyneimpiä pioneereja, jonka julkaisutoiminta alkoi jo 1980-luvulla moskovalaisen Donskoin luostarin Svetljatšok-kustantamon piirissä, yhdessä nykyisen metropoliitta Tihon Ševkunovin kanssa. https://www.labirint.ru/authors/81463/
} 
- Minä uskon Venäjään, minä uskon sen oikeauskoisuuteen... Minä uskon Kristuksen ruumiiseen...minä uskon, että toinen tuleminen tapahtuu Venäjällä...Minä uskon...

Šatov mutisi raivoissaan.

- Entä Jumalaan? Jumalaan?

- Minä... uskon joskus tulevaisuudessa Jumalaan.

(Dostojevski 1982, osa I, 282.)

Dostojevskin ajattelun ytimessä on pyrkimys universalismiin, mikä kansalaisuskonnon kehyksessä vähitellen kuitenkin on muovautunut imperialistiseksi ja kulkeutunut sellaisena neuvostoideologiaan. Tässä katsannossa marxismi-leninismi on kansalaisuskonnon äärimuoto, jonka oppi artikuloidaan puoluekokouksissa. Harhaoppisia vastaavat luonnollisesti päälinjasta poikkeavat trotskilaiset, maolaiset, titolaiset jne. Vladimir Lenin on uuden uskonnon kuolematon jumalhahmo, jonka reliikit on haudattu mausoleumiin. Neuvostotutkijoiden kuului siteerata Leninin teoksia, kuten teologien kuuluu siteerata Raamattua. Uusi uskonto tuli ilmi Leninissä, joka "toteutti" Karl Marxin ja Friedrich Engelsin profetiat. (Hovorun 2017).

Kuten puolestaan sosiologi Oleg Kharkhordin on kuvannut, Leninin seuraajaksi pääsy tapahtui hierarkkisen initiaation kautta. "Vihkiytyneet" vastasivat myös harhaoppisten paljastamisesta/ilmiantamisesta (oblitšenie) (Kharkhordin, 1999, 2002). Puolueen jäseneksi pääsy kulki ihannemuodossa lokakuulaisista, joihin liityttiin seitsemän vuoden iässä, pioneereihin viidentoista vuoden iässä. Sieltä "ansioituneimmat" nuoret valikoituivat Komsomoliin ikään kuin diakoneiksi, ylemmän papiston ollessa kommunistipuolueen jäseniä (Hovorun 2017, 257).

Uudella Venäjällä kansalaisuskonto otti aineksia neuvostoideologiasta ja imperialismista. Tällöin ortodoksikirkko omaksui johtavan agendanmäärittelijän roolin. Gulagin muistiperintöä ja -paikkoja Venäjällä tutkinut puolalainen sosiologi Zuzanna Bogumil on esimerkiksi todennut, että kirkko voitti Moskovan liepeillä sijaitsevan Butovon ${ }^{7}$ massateloituspaikan muistiperinnön haltuunotossa maallisen kansalaisjärjestö Memorialin siksi, että kirkolla oli tarjolla ihmisten ymmärtämä kieli käsitellä asiaa. Memorial toivoi tuomiota syyllisille viranomaisille ja toivoi heidät itse puhdistavan itsensä, kun taas ortodoksinen kirkko uskoi kaiken tuomiovallan kuuluvan yksin Jumalalle. Tässä prosessissa kirkon onnistui yhdistää puhdistautuminen kansallistunnon uuteen heräämiseen.

\footnotetext{
${ }^{7}$ Butovon tilalla sijaitsi NKVD:n salainen massateloituspaikka, jonka olemassaolo paljastui vasta perestroikan aikaan. Suuren terrorin aikana vuosina 1937-1939 siellä teloitettiin yli 20000 henkeä, mukaan lukien ainakin tuhat kirkonmiestä. Butovon kompleksi on sittemmin muodostunut tärkeäksi maalliseksi ja kirkolliseksi muistopaikaksi, sekä viime vuosina yleiseksi virkistys- ja kulttuuripuistoksi.
} 
Memorialilta sen sijaan puuttui väline myönteisen näköalan luomiseen. (Bogumil 2018, 197, passim.)

Tähän sinänsä keskeiseen havaintoon on kuitenkin syytä lisätä, että viimeisten kymmenen vuoden aikana tilanne on luonnollisesti jo toinen. Butovon salaisuuden paljastumisesta on kulunut jo yli kolmekymmentä vuotta. On kuvaavaa, että hankkeen yhden keskushenkilön, paikalla vuonna 1937 teloitetun papin pojanpoika, itsekin pastori, Kirill Kaleda ei enää edusta opposition ääntä, vaan valtaeliittiä. Uskonnollinen renessanssi on tälle vuosikymmenelle tultaessa jo ohitettu vaihe. Uskovaisten ydin on pieni, kun taas maallisen vallan kanssa liittoutunut ja valtavirtaistunut kansalaisuskonto tarjoaa jotain kaikille ja on siksi kansalaisia yhdistävä suurin yhteinen nimittäjä.

Cyril Hovorunin mukaan venäläisen ortodoksikirkon lipsumista kansalaisuskonnoksi ilmentää sen taipumus tarjota oma kielensä välineeksi puhua "ei Jumalasta, vaan sosiaalisista ja poliittisista arvoista, joiden on määrä konsolidoida Venäjän kansa poliittisen hallinnon ympärille. Kirkon luvalla kansalaisuskonto muovaa teologian ideologiaksi”. Pitäessään kynnyksen matalalla kirkko kansalaisuskontona eroaa normatiivisesta kristinuskosta ja samalla sallii siihen yhteen sopimattomien hahmojen kuten Nikolai II:n lukemisen pyhien joukkoon, sekä Josif Stalinin pääsyn "lyhyelle listalle". (Hovorun 2017, 258.)

Hovorunin mukaan normatiiviseen kristinuskoon verrattuna kansalaisuskonto on monin tavoin väljähtynyttä (reduktionistista). Koska kansalaisuskonto syntyy kansan kokemasta omasta ainutlaatuisuudestaan ja erityismissiostaan, syöttiläänä sen patriotismi ihroittuu nationalistiseksi. Venäjän tapauksessa edustuksellisen demokratian keinot ovat riittämättömät. Siksi kansalaisuskonto korvaa demokratian puutteita legitimoimalla hallintoa ja nojaamalla konservatiivisiin ja patrioottisiin (nationalistisiin) arvoihin. Kirkon ja maallisen hallinnon yhteispeli pyrkii muokkaamaan arvoista ortodoksisen kulttuuris-poliittisen identiteetin. Metafyysisen jumalasuhteen asemesta valtio nojaa institutionaaliseen ulkoiseen moraalisuuteen, etiikkaan, ja kohdistaa moraaliaseen "toisiin". Venäläis-ortodoksinen kansalaisuskonto suosii retoriikassaan kaikkivaltiasta voimakasta Jumalaa pelastavan Kristuksen sijaan. Sen retoriikka on dualistista (kahtiajakavaa), ja poliittinen polarisaatio on ilmaistu uskonnon kielellä. Kun kahtiajako "meihin" ja "muihin" on kaikkien ymmärtämä, niin kansalaisuskonto "tyhmenee" ja muokkautuu kohti diktatuuria (Hovorun 2017, 260-262).

Mielestäni nimenomaan kansalaisuskonnon dualismi auttaa ymmärtämään, ettei kylmä sota voi olla päättynyt, sillä sen ajaton jakolinja kulkee läpi niin idän ja lännen, Moskovan patriarkaatin ja Konstantinopolin ekumeenisen patriarkaatin, ortodoksien ja "latinalaistajien". Epämiellyttävässä 
skenaariossa kahtiajako syvenee. Kansalaisuskonnon tuputtaminen lienee myös syy siihen, että viime vuosina Venäjän intellektuellit, joilla tarkoitan ns. liberaaleja sekulaareja vastakohtana vallassa olevien konservatiivien hegemoniselle projektille (ks. Kivinen \& Humphreys 2020), ovat vieraantuneet kirkon päälinjasta. Vieraantuminen seuraa siitä, että he eivät voineet tuomita liberalismia harhaopiksi, tai valikoiden tuomita seksuaalisia syntejä ja samalla hyväksyä korruptiota, tai ylipäänsä harjoittaa jakolinjaa meihin ja muihin. Tässä roolissa kirkko ei enää edusta kristinuskon lupausta vapaudesta. Uusimpien mielipidekyselyiden mukaan venäläiset luottavatkin nyt valtakirkon sijaan eniten armeijaan. ${ }^{8}$ Armeija on onnistunut hyödyntämään "suurta sotaa" pehmeässä vaikuttamisessaan.

"Suuren sodan" ja pyhän vihan hyödyntäminen hengellisessä maanpuolustuksessa

Koska "suuri sota" kosketti koko kansakuntaa ja sen muistoperintö on muodostunut suurimmaksi yhteiseksi nimittäjäksi, on kansan erityiseen uhrivalmiuteen helppo vedota. Kun järjestelmämuutosta seurannut uskonnollinen renessanssi oli jo vuoden 2003 tienoilla saavuttanut lakipisteensä, siirryttiin uuteen vaiheeseen - maanpuolustuksen nostamiseksi kärkeen. Samoihin aikoihin 1900-luvulla eläneiden marttyyrien ja tunnustajien kanonisaatiot vähitellen tyrehtyivät, salaisten arkistojen ovet menivät jälleen kiinni ja kirkko oli omaksunut patriotistisarvokonservatiivisen propagandistin toimijuuden yhteispelissä maallisen vallan kanssa. "Suuren ja pyhän sodan” sanoman tehokas levittäminen kirkon myötävaikutuksella lisäsi armeijan arvostusta. Tämä on todennettavissa tarkastelemalla sota- ja uskontoaiheisten kansanpainosten määrää ja sisältöä, samoin kuin armeijan ja maanpuolustusjärjestöjen toiminnan nykyaikaistumista. Tai jopa pukeutumisen perusteella: maastokuvioidut miestenasut ovat suosittuja myös siviileillä, samoin yrjönnauhatunnukset ja sotaan viittaavat iskulauseet erityisesti merkkipäivinä. Hengellinen maanpuolustus on erittäin laajaa, mistä nostan seuraavaksi esimerkkejä.

Sotilaalliseen uhkaan valmistautuminen edellyttää jatkuvasti ylläpidettävää tietoisuutta vihollisesta ja siihen liittyvää mielikuvamaailmaa. Hegemoninen valta peräänkuuluttaa myös siviilien - kuten sotilaiden omaisten - uhrivalmiutta. Ydinsukellusvene "Kurskin" rauhanaikainen onnettomuus Barentsinmerellä elokuussa 2000 on sille Badanin (2013) omistamassa muistoteoksessa kuvattu

\footnotetext{
${ }^{8}$ Elokuussa 2020 Levada-keskuksen mielipidekyselyn mukaan 66\% aikuisista luottaa instituutioista eniten armeijaan, 58\% presidenttiin, 53\% FSB:hen ja turvallisuuselimiin, 42\% kirkkoon ja uskonnollisiin järjestöihin. https://www.levada.ru/2020/09/21/doverie-institutam/.
} 
ylevöitettynä, mystissävyisenä sotilasuhrina. Turmassa menehtyneen koko 118 hengen miehistön muistoksi on Vidjajevon tukikohdassa pystytetty muistokappeli. Uhrien muotokuvat on ikuistettu valkeissa kastevaatetta muistuttavissa paidoissa ikonin sivukuviin. Vidjajevossa ja muissa laivastotukikohdissa heidän sieluilleen rukoillaan lepoa yhä, kuten on tehty jo yli kahden kymmenen vuoden ajan.

Uhrien muiston kirkollistaminen ja erityisesti heidän muotokuviensa maalaaminen ikonin reunuksiin on myös herättänyt kritiikkiä. Vain murto-osa "Kurskin" miehistöstä oli näet uskontoa harjoittavia (votserkovljonnye) ortodokseja, muut olivat joko uskonnottomia tai nimensä ja kotipaikkansa (kuten Baškortostan) perusteella muslimeja (Mitrofan, 2013, 106) Tämän vuoksi muistokappelin rakentajat saivat osakseen myös suoranaista paheksuntaa.

Kansalaisuskontokehyksen mukaisesti tulkiten, tässä tilanteessa hankevastaavat toimivat matalan kynnyksen periaatetta noudattaen. Olennaista on, että julkinen, kollektiivinen pyhä - "omine" yhteisine Pohjoisen laivaston synty- ja suuren sodan aikaisine sankaritarinoineen, rituaaleineen, uhrauksineen ja jatkuvuuksineen - on keskeisellä sijalla, kun taas miehistön uskontokuntien välisillä eroilla ei ole asian kannalta merkitystä ja ne voi häivyttää. Tuolloinen Murmanskin piispa Simon totesikin: "Heidän marttyyriuhrinsa kastoi heidät merivedellä” (Mitrofan, 2010, 63). Vidjajevon muistokappelin symboliikka suojelusikoneineen ja valkopaitaisten merimiesten reunuskuvineen teroittaa mieliin viattomien uhrausta kansakunnan jatkuvuudelle ja ylläpitää yhteisön itseymmärrystä. On muistettava, että Vidjajevon perspektiivistä katsoen Moskova on kaukana. Hovorunin (2014) kritiikki kansalaisuskontoa kohtaan ei mielestäni riittävästi kohtaa nyky-Venäjän sotilaallisen paikallisyhteisön realiteetteja. Vaihtoehdot paikallisyhteisössä ovat näet vähissä, ja sotilasura on haluttu. Koulu, kirkko ja armeija puhuvat samaa kieltä (Kivinen 2011).

“Kurskin” onnettomuuden hyödyntämistä pyhä sota kansalaisuskontona -kehyksessä voi seurata muuallakin, kuten muistopaikalla pietarilaisella Serafimovskojen hautausmaalla, jonne on haudattu paljon erilaisissa palvelustehtävissä menehtyneitä siviilien ohella. Siellä lepäävät myös 14 Kurskin uhria, joiden mustat graniittipaadet muotokuvineen ovat huomiota herättävän arvokkaat. Osaan paasista on kaiverrettu ortodoksiristi, osaan ankkuri, joka myös on kristillinen symboli. Lisäksi aaltojen yllä kaartuu suurisiipisen merilokin veistos sekä merellä kulkijoiden suojelijan pyhittäjä Nikolaoksen ikonilla varustettu paasi. Jälkimmäiseen on kaiverrettu usein käytetty jae Johanneksen evankeliumista: "Suurempaa rakkautta ei kukaan voi osoittaa, kuin että antaa henkensä ystäviensä puolesta" (Joh. 15:13). Sama jae kaiverrettiin esimerkiksi Moskovan kenraalikuvernöörin, suuriruhtinas Sergei Aleksandrovitšin muistoristin laattaan hänen salamurhapaikalleen (vuonna 1905) lähellä Kremliä. Henkensä antamista pyhänä uhrina teroitetaan myös silloin, kun kyse on 
rauhanaikaisista onnettomuuksista. Onkin sanottu, että rauhan ja sodan välinen raja on hämärtynyt (Jonsson, 2019).

Mitrofanin "Suuren sodan salaisuus" (2020) teroittaa suorasanaisesti sotilaan oman henkensä uhraamista ylimpänä uhrina, johon sotilas tietoisesti valmistautuu. Teos samoin kuin Zobernin "Jumala ja voitto" (2014) pyrkii neuvostoajan historian uudelleen tulkintaan pyhän sodan kuvastoa ja muistiperintöä hyödyntäen. Molemmissa teoksissa korostuvat viittaukset venäläisen jumalankantajakansan erityislaatuun, sen messianistiseen tehtävään ja Kolmannen Rooman ideologiaan. Kansalliseen ideologiaan vetoaminen tapahtuu reduktionistisen vastakkainasettelun hengessä, Mein Kampfiin peilaten, Kolmas valtakunta perivihollista esittäen. "Mystisessä” sodankäynnissä Kolmas valtakunta kohtaa Kolmannen Rooman; aina ja yhä uudelleen. Sodan pyhittäminen on historian ulkopuolella, viholliskuva on muuttumaton, eikä periviholliselle fasistin naamion takana voi antaa anteeksi, vaikka uskovaiset niin saattavat ajatella.

Kirjoittajat ottavat näin kantaa viime aikojen keskusteluissa uudelleen esiin kaivettuun kysymykseen "Voiko fasisteille antaa anteeksi?", jota Moskovan patriarkaatin aikakausjulkaisun vuoden 1945 toukokuun numerossa pappi N. A. Harjuzov (1945) tuoreeltaan käsittelee. Harjuzovin lähtökohtana ovat katolisen kirkon tuolloiset vetoomukset kansainväliselle yhteisölle anteeksiannosta fasisteille sekä Moskovan patriarkaatin kyseisten vetoomusten jyrkkä tuomitseminen. Jeesuksen sanoja ristillä ”Isä, anna heille anteeksi, sillä he eivät tiedä mitä tekevät." (Lk. 23:34) ei kirjoittajan mukaan voi soveltaa koskemaan fasisteja, jotka hyvin tiesivät mitä tekivät. Jeesus ei myöskään rukoillut Juudaksen puolesta, vaan sanoi "Parempi olisi sille ihmiselle, että hän ei olisi syntynyt.” (Mk. 14:21). Tärkeä jae on myös 5. Mooseksen kirjan 32:35: "Minun on kosto ja rankaiseminen", josta tavallisesti siteerataan vain tuo jakeen alkuosa. Kiinnostavaa nykytutkijan kannalta on, että 2010-luvun kirjoittajat, kuten Mitrofan ja Zobern, eivät ole tuoneet Harjuzovin poliittiseen teologiaan mitään muuta uutta, paitsi eksplisiittisen mystisen sodankäynnin "Kolmas valtakunta kohtaa Kolmannen Rooman".

Varmemmaksi vakuudeksi kumpikin kirjoittaja siteeraa antaumuksella Hitlerin Mein Kampfia. "Suuren sodan salaisuuden" lukija saa muistutuksen, miten Hitler oli päättänyt valloitettujen alueiden eli inspektoraattien keskusten uusista nimistä: Kiovasta tulisi Baden, Bakusta Westfalen, Moskovasta Saksonia, Leningradista Holstein (Mitrofan 2020, 145). Zobern on vasta nyt tutustunut 1943 ilmestyneeseen, Stalinin vaikeassa sotatilanteessa kirkon miehiltä tilaamaan ja kiireessä painattamaan propagandateokseen "Totuus uskonnosta Venäjällä” (Pravda o religii v Rossii, 1943), 
joka ilmestyessään useilla kielillä oli sensaatio. Se julkisti "koko maailmalle” eli eurooppalaisille liittolaisille Stalinin kädenojennuksen kirkolle ja pyrki häivyttämään epäluulot uskovaisten vainoamisesta. Tässä ja nyt Zobern siteeraa "Totuuden" kuvauksia (joita metropoliitat kuvaannollisesti pistooli ohimolla kirjasivat Stalinin "tilauksesta" ylös) laveasti ja kritiikittömästi, ikään kuin eläisi vuodessa 1943. Lisävaloa kuitenkin tuovat myös ääninauhat, jotka on tallennettu kuuluisasta Stalinin kokoon kutsumasta piispojen tapaamisesta syyskuun alussa 1943 (Zobern 2014, 122-140). Tärkeä pyhän sodan nykyapologian kulminaatio onkin se, kun Stalin, ateistisen valtakunnan ja poliittisen maailmanliikkeen johtaja, tarvitsee kirkolta apua.

\section{Kun Stalin tarvitsee kirkkoa}

Stalin oli sodan kuluessa ymmärtänyt länsiliittolaistensa tarvitsevan todisteita siitä, ettei kirkkoa Neuvostoliitossa vainota. Käänne alkoi siitä, että Moskovan patriarkan sijainen Sergii (Stragorodski), Leningradin metropoliitta Aleksei (Simanski) ja Ukrainan, Kiovan ja Galitsian metropoliitta Nikolai (Jaruševitš) kiidätettiin keskellä yötä Kremliin Stalinin kutsusta. Isäntä ehdotti, että pääkirkot pitäisi avata ja pappien asemaa parantaa (luvaten autoja ja polttoainetta, lämpimän huoneiston Tšistyi pereulokilta, valtion elintarvikkeita). Lisäksi tulisi pappiskoulutus ja julkaisutoiminta käynnistää sekä kutsua synodi kokoon pikimmiten.

Vierailun tuloksena neljä päivää myöhemmin 8.9.1943 synodi kokoontui ja patriarkan istuin palasi Moskovaan. Muut ehdotukset pantiin nekin bolsevikkien tempolla toimeen. Pappisseminaarit ja Hengellinen akatemia avasivat ovensa, yliopistoon palasi Bysantin tutkimuksen oppiaine, piispojen saarnat ja julkaisutoiminta sallittiin. Pappeja vapautettiin telkien takaa. ”Totuus uskonnosta Venäjällä” (1943) avasi kokonaisuudessaan Stalinin ajattelua. Hän näki itsensä Iivana Julman seuraajana ja Kolmannen Rooman idean puolustajana. Tähän päähänpinttymään on kukin suuri venäläinen johtaja omalla valtakaudellaan ottanut kantaa. Venäjä on eri vuosisatoina yhä uudelleen pyrkinyt valloittamaan Konstantinopolin takaisin kristityille. Sotilaallisesti sen pyrki toteuttamaan moni, Katariina Suuresta aina Staliniin.

Esipaimenet organisoivat rahankeruun, ja niin kirkko keräsi lyhyessä ajassa uskovaisilta 300 miljoonaa ruplaa. Varat käytettiin neljänkymmenen T-43 -tyyppisen panssarivaunun lahjoittamiseen armeijalle. Nämä panssarivaunut nimettiin soturipyhittäjäprinssi Dmitri Donskoin mukaan. Vastaavasti lennosto täydentyi toiselle merkkipyhälle, Aleksanteri Nevskille, nimetyin hävittäjin. Tätä uskomatonta käännettä ja voimannäytettä ei tietenkään ole mitään syytä unohtaa tai vähätellä. Kuten Zobern kirjoittaa: "Toisin kuin ateistit olivat suunnitelleet, niin tuona vuonna ei pappeja ja 
kirkkoja kohdannut täysi tuho, vaan maan historian hirvein sota asetteli asiat paikoilleen" (Zobern 2014, 140). Apologiassa sota oli rangaistus jumalankantajakansan isiensä uskon hylkäämisestä.

Metropoliitta Mitrofan (2020) määrittelee vastustajien uskon liittyvään okkultismiin ja saatananpalvontaan. "Omien" synnin hän näkee luopumiseen jumalankantajakansan missiosta oikeaoppisten leniniläisten vallankumouksellisten johdolla, mistä rangaistuksena seurasi verinen suursota. Hänen ja Zobernin (2014) näkemykset edustavat nykyistä valtavirtaa aina Ilmestyskirjan siteerauksineen. Vastaavaa visuaalista tulkintaa näkee uusien uuspyhille omistettujen kirkkojen interiöörien kuvaohjelmissa. Niissä enkelit puhaltavat pasuunaan joukkoteloituspaikka Butovonkin kirkossa, veljessodassa sotilaat teloittavat omia piispoja, ja Juudas hirttäytyy puuhun petettyään ahneudesta Herransa ja kaduttuaan tekoaan.

Nykyaikaista termiä käyttäen metropoliitta kirjoittaa: "1941 kimppuumme hyökkäsi yhtynyt fasistinen Eurooppa”. Bismarckia siteeraten eurooppalaisten ei olisi kannattanut hyökätä venäläisten "hölmöilyä" vastaan. Näiden ei olisi kannattanut ryhtyä epätoivoiseen taisteluun - sillä, "mikä saksalaiselle on absurdia, on venäläiselle moraalinen voitto". Kiinnostavin yksityiskohta on "yhtyneen fasistisen Euroopan" (objedinjonnaja fašistkaja Jevropa) viholliskuva, millä Mitrofan tarkoittaa akselivaltojen liittolaisia, mutta sanavalinta vihjaa nykyiseen Euroopan unioniin. (Mitrofan 2020, 86, 81). Fasistileiman käytön retorinen kynnys onkin madaltunut, mikä on osoitus vastakkainasettelun syventymisestä.

Metropoliitta Mitrofan käsittelee laajasti Stalinin sodanaikaista kirkkopolitiikkaa ja legitimoi kansan syvien rivien luottamuksen generalissimukseen pyhän sodan johtajana. Edellä mainittu alkusyksyn 1943 metropoliittojen tapaaminen Kremlissä ei syntynyt ilman edeltävää kehitystä. Stalin puhutteli radiossa kansaa jo syksyllä 1941 saksalaisten ollessa 30 km etäisyyden päässä Kremlistä Himkin esikaupungissa sanoin "veljet ja siskot”, mikä oli kristillisyydessään ennenkuulumatonta.

Samoina kohtalonhetkinä ennen kuulematon "Pyhä sota" -laulu alkoi kaikua päivin ja öin kovaäänisistä, ja historian sankarit astuivat taas esiin. Esimerkiksi jo mainittu Dmitri Donskoi ja puolalaiset vuonna 1612 tiehensä ajanut kansallissankari Kuzma Minin ilmestyivät katujulisteisiin. Pyhän sodan missiosta voi nähdä merkkejä taiteessa, tunnetuimmin Sergei Eisensteinin suurelokuvissa. Siinä missä 1938 valmistunut Aleksanteri Nevski näytti päähenkilön uskonnottomana, joka ei kertaakaan tee edes ristinmerkkiä, on 1944 valkokankaalla esitetty Iivana Julma täysin Kolmannen Rooman ideologian läpäisemä, Stalinin uskonnollis-poliittisen projektin kuuluisin taide-esitys. 
Suullisen perimän mukaan edellä kuvatuilla signaaleilla oli valtava vaikutus kansalaisten taistelutahtoon. Suositun legendan mukaan sokea ennustaja Matrona Moskovalainen ennusti Stalinille Kremlissä tämän voittavan sodan ja pysyvän kaupungissa vahvistamassa kansan mielialaa. Sodan jälkeen Matrona lausui toisen ennustuksen, jonka mukaan Jumala ehkä antaa Stalinille anteeksi sen tähden, mitä hän sodassa teki. Populaareissa lähteissä Stalinin henkivartiosto on kertonut ylipäällikön viettäneen pitkiä aikoja mietiskelemässä Kremlin tyhjässä kirkossa.

Sinänsä vähäiset, mutta tarkkaan merkille pannut signaalit loivat ylipäällikölle uskon palauttajan sädekehää. Ihmeitätekevää, voitollista Kazanin Jumalanäidin ikonia lennätettiin Možaiskin rintamasuunnan juoksuhautojen yllä ja myöhemmin Stalingradin yllä. Ehtoollisleipää ja -viiniä alettiin varata 1941-1942 Leningradin ja Moskovan harvoihin toimiviin kirkkoihin. Vuonna 1942 Pääsiäisen vietto sallittiin ja kahta vuotta myöhemmin upseerienkin oli lupa osallistua juhlajumalanpalvelukseen. Myös papit saivat ohjeistuksen, miten huomioida saarnassa lokakuun vallankumouksen merkkipäivä. Suoraa ulkomaista tukea ylipäällikkö sai Antiokian kirkon Libanonin vuorten metropoliitta Ilja Karamilta (Mitrofan 2020, 91, passim).

Mitrofanin mukaan Stalin kutsui kirkon johtajat 5. syyskuuta 1943 neuvonpitoon Kremliin strategisesti oikealla hetkellä - taustanaan uskomattomat voitot Stalingradin ja Kurskin taisteluissa. Tätä ei olisi voinut tapahtua ilman, että politbyroon johdosta oikeaoppiset leniniläiset olisi puhdistettu. Stalinille kyse oli Kolmannen Rooman puolustuksesta, yrityksestä saada haltuun Konstantinopoli ja Mustanmeren salmet. Tämän valloitustavoitteen Mitrofan tulkitsee eskatologisessa valossa, "painon alla elävän pyhän Venäjän roolista [Antikristuksen] pidättelijänä (uderživajuštšego)" (2.Tess. 2,7) (Mitrofan 2020, 135).

Jo sodan jälkinäytökseen kuului patriarkka Aleksi I:n vierailu Jerusalemiin 1945. Stalin teki aloitteen Israelin valtion perustamisesta, minkä Israel palkitsi palauttamalla Neuvostoliitolle keisarien kirkollisen omaisuuden sen maaperällä. (Mitrofan 2020, 121-122.) Omaisuus ei ollut vähäinen, sillä Palestiinan ja Venäjän väliset kauppa- ja pyhiinvaellussuhteet olivat Romanovien vallan loppupuolella todella vilkkaat. Vähävaraisillakin oli mahdollisuus käydä Pyhällä maalla. Aatteellisesti Pyhän maan ja Venäjän suhteiden korostaminen on aina kietoutunut Kolmannen Rooman idean puolustamiseen.

Stalinin sodanjälkeinen kirkkopolitiikka kukoisti aina vuoteen 1948, jolloin itäblokin edustajat kokoontuivat Moskovaan juhlimaan Venäjän kirkon 500 vuoden itsenäisyyttä (autokefalia). Tämän jälkeen suunta muuttui: uusia kirkolle myönteisiä askelia Stalin ei enää ottanut, suuri pyhä sota oli siltä erää ohi. Hänen seuraajansa Hruštševin politiikka oli kirkolle perin karvas. Pahinta oli 
keisarien kullan eli kirkollisen omaisuuden, jonka Israel oli tunnustanut kuuluvan SNTL:1le, takaisinmyynti sille 7.10.1964. Vastineeksi kaupassa saatiin muun muassa appelsiineja, mikä kyllä toi Hruštševille potkut (Mitrofan 2020, 123).

Kiinteä osa pyhän sodan apologiaa on vahvan johtajan kunnianpalautus. Mitrofanin mukaan "Stalin on osa suunnatonta kipua ja kuihtumatonta mainetta" (Mitrofan 2020, 105-106). Stalinistiset uskovaiset ovat sitä mieltä, että tämä "yksin puolusti uskoa", ja kirkkoveisuja saattoi laulaa vain yhdessä politbyroon sisäpiiriläisten Molotovin ja Vorošilovin kanssa, jotka hekin olivat lapsuudessaan laulaneet kirkkokuorossa. Jouduttuaan epäsuosioon kolmas avainministeri, Georgi Malenkov, puolestaan tuli uskoon. Kirkon päälinjaa, "Jumala rankaisee”, noudattaen Mitrofan ja Zobernkaan eivät puolustuspuheessaan Stalinin maineen puolesta ota kantaa tämän rikoksiin.

\section{Ulkopolitiikkahyöty nyt}

Pyhän sodan teemaa, kahtiajakoa hyviin ja pahoihin, sekä vahvan johtajan kulttia voi hyödyntää ulkopoliittisessa retoriikassa myös nyt, ns. ulkoisessa pehmeässä vaikuttamisessa. Niin oudoilta tieteiskirjallisuuteen kuuluvilta kuin mystiset pyhät sodat saattavat sekulaarien liberaalien tai sellaisina itseään pitävien korvissa kuulostaakin, on muistettava, että maailmalla ne eivät ole harvinaisia. Donald Trumpin presidenttikaudella vastaavalle on ollut paljon kysyntää Yhdysvalloissakin. Osa evankelikaalisia on omaksunut Venäjän ortodoksisen kirkon propagoimia arvoja ja löytänyt agendoissaan yhteensopivia nimittäjiä viholliskuvissaan. Yhtymäkohtia tarjoavat abortin vastustaminen, konservatiiviset perhearvot, valkoisen rodun ylivalta, aseellinen puolustus, vakaumus oman asian ainutlaatuisuudesta ja kokemus messiaanisesta poliittisesta johtajasta.

Yhteistä säveltä on harjoiteltu Moskovan patriarkaatin alaisen ROCOR:n (=Russian Orthodox Church Outside Russia eli Venäjän ort. kirkko ulkomailla) seurakunnissa ja virtuaaliyhteisöissä, ns. digitaaliortodoksian parissa (Suslov 2016). Yhdysvaltalaisen antropologi Sarah Riccardi-Swartzin (2020) havaintojen mukaan ROCOR on Yhdysvalloissa vetänyt puoleensa koulutettuja protestanttisia äärikonservatiiveja, joilla ei ole etnistä tai kielellistä kosketuspintaa Venäjään, mutta joille länsimainen feminismi, sukupuolivähemmistöjen oikeudet ja transgenderismi ovat punaisia vaatteita ja moraalipaniikin aiheuttajia. ROCOR saattaakin olla vaikuttajataho, jonka piirissä kristikunnan globaalin puolustajan roolia voidaan kehitellä ilman kansallisia historiallisia painolasteja. Vastakäännynnäisten keskuudessa voi olla kiinnostavaa testata, mikä toimii. Tähän kysymykseen en sukella sen enempää, vaan palaan lopuksi pyhän sodan poliittis-uskonnolliseen kehystämiseen venäläisen menneisyydenhallinnan näkökulmasta. 
Koska toisen maailmansodan muistoperintö on koheesion tuottajana ylitse muiden yhteisten nimittäjien, ei sen uhrauksen kyseenalaistajia - kuten esimerkiksi ukrainalaisia "nationalisteja, fasisteja, banderalaisia”, kuten haukkumalitania kuuluu - voida hyväksyä. Tämä on aivan sen mukaan, mitä vuonna 1945 kirkko esitti (Harjuzin 1945). Kirkon ulkopoliittinen missio on yhä tänään retorisesti sidottu sivilisaatiovalintaan ja pyhään sotaan, katkeamattoman jatkumon esityksenä. Käsite on oivallisesti hyödynnettävissä myös suhteissa muslimimaihin, mistä ortodoksikirkon ja traditionaalisten muslimien välisiin yhteyksien systemaattinen huomioiminen kertoo. Esimerkiksi Syyrian operaatiota ja Assadin hallinnon tukemista on systemaattisesti puolustettu kristinuskolle tärkeiden historiamuistomerkkien pelastamisena. Patriarkka Kirill muistuttaa jatkuvasti, että muslimit tukevat Venäjän ortodoksikirkkoa ehdoitta, esimerkiksi kun patriarkaattiin kohdistui hiljattain väkivallan uhka. Sen sijaan läntisten kristillisten kirkkojen kanssa yhteisen sävelen löytyminen on pelastusoppiin liittyvistä syistä mahdotonta (Kirill 2020).

\section{Lopuksi}

Esseeni pohti, mikä sodassa on niin pyhää, että sen muistoon yhä aina vain pitää palata. Tai miksi kahtiajako "omiin" ja "vieraisiin" on niin ehdoton, että sen kirkastamiseksi kirkko, maallinen valta ja armeija ovat tiivistäneet rivinsä aivan kuten vuonna 1943. Ehdotin vastaukseksi "suurimman yhteisen nimittäjän” käypää selitystä, johon kukin Venäjän mahtijohtajista on vuorollaan tukeutunut, ottaen aiempien johtajien versiot 'Kolmannesta Roomasta' huomioon ja soveltaen niitä omalla tavallaan, aina pohjimmiltaan leppymätöntä kahtiajakoa, reduktionismia, Venäjän kansan erityismissiota ja vahvan johtajan ideaalia uusintaen.

Käsittelin myös vahvan johtajan ja pyhän sodan yhtälöä, ja sitä, miten monipuolisesti - ja ilmeisen tehokkaasti - niiden muistiperintöä levitetään. Kansalais- tai poliittinen uskonto on eräs lähestymistapa ajankohtaiseen teemaan. Tässä kehyksessä pohdin, mitä "sivilisaatiovalinta", "mystinen /pyhä sota" tai "pyhä viha" merkitsevät ja mitä niillä ajetaan takaa. Samalla kun niiden avulla rakennetaan omaa erityisyyttä, "toinen" demonisoidaan ikuiseksi fasistiksi, kosmiseksi viholliseksi, jolle ei ihmisen ole lupa antaa anteeksi. Sovinnosta puhuminen koetaan oi, radikalismiksi, kun taas kansalaisuskonto on sopiva sankarikansan tarinan muotti, ja sille Venäjällä riittää käyttöä.

Esittämäni tulkinta ei tietenkään sulje pois muita tulkintoja, eikä liioin tee kirkosta yhtään vähemmän pyhää uskovaisten seurakuntana. On kuitenkin valitettavaa, että vaikka sotaisasta 
retoriikasta sekä sodan ja rauhanajan välisestä häilyvyydestä on pätevää tutkimusta tarjolla, ei tietoa kenties riittävästi oteta huomioon. Helpompi on aina vain puhua ohjuksista.

Kenties pyhä sota kansalaisuskontona -teeman käyttökelpoisuus on juuri sitä, että kriisin osuessa kohdalle ei ole sijaa saivarrella, onko jokin oppi tyhmää tai primitiivistä, riittää, kunhan se mobilisoi joukot. Venäjän pyhän sodan oikeutuksen sanoma on aina sama: ei ole väliä, mikä on sotilaan henkilökohtaisesti harjoittama uskonto, vaan että hän on valmis antamaan henkensä ystäviensä puolesta, oli sota kuuma tai kylmä. Tarvitaan myös kollektiivinen kokemus riittävän suuresta hädästä, jota ilman ei ole pelastuksen kokemusta. Tai kuten sananparsi sanoo: Joka ei ole merta kyntänyt, ei ole Jumalaa rukoillut.

\section{Elina Kahla}

\section{Kirjallisuus}

Bellah, Robert N. (1967), Civil religion in America. Reprinted by permission of Dadalus, Journal of the American Academy of Arts and Sciences, from the issue entitled "Religion in America," Winter 1967, 96:1, 1-21.

Bellah, Robert N. \& Philip Hammond (1980), Varieties of Civil Religion. San Francisco: Harper \& Row.

Bogumil, Zuzanna (2018), Gulag Memories. The Discovery and Commemoration of Russia's Repressive Past. N.Y.: Berghahn.

Dostojevski, Feodor (1982), Riivaajat I-II. Suom. Lea Pyykkö. Hämeenlinna: Karisto.

Harjuzov, N. A. (1945), Možno li prostit fašistov? (Mysli pravoslavnogo svjaštšennika). - Žurnal Moskovskoi Patriarhii. 5/1945. http://archive.e-vestnik.ru/page/index/194505360.html.

Hosking, Geoffrey (2006), Rulers and victims: the Russians in the Soviet Union. Cambridge: Harvard University Press.

Hovorun, Cyril (2017), "Civil religion in the Orthodox Milieu”. - Political Theologies in Orthodox Christianity: Common Challenges and Divergent Positions. Ed by Kristina Stoeckl, Ingeborg Gabriel, and Aristotle Papanikolaou. London: Continuum, 253-262. 
Jonsson, Oscar (2019), The Russian Understanding of War: Blurring the Lines between War and Peace. Washington: Georgetown University Press.

Kangaspuro, Markku (2020), Aleksanteri-instituutin etäluento (RUS-311) "Culture and Identity", 30.9.2020

Kharkhordin, Oleg (1999), The Collective and the Individual in Russia: A Study of Practices.

Berkeley: University of California Press.

Kharkhordin, Oleg (2002), Oblitšat i litsemerit: genealogija rossiiskoi litšnosti. St. Petersburg and Moscow: EUSPb, Letnii sad.

Kirill, patriarkka (2020), [Opetuspuheohjelma] Slovo pastyrja. 21.11.2020.

https://www.1tv.ru/shows/slovo-pastyrya.)

Kivinen, Markku (2011), Valta Venäjällä. - Tiedosta toimintaan: Kirjoituksia korkeakoulutuksesta, filosofiasta ja yhteiskunnasta. Osmo Kivisen juhlakirja. Toim. Sakari Ahola, Päivi Kaipainen, Olli Koistinen, \& Kari Nyyssölä. Turku: RUSE University of Turku, 182-191.

Kivinen, Markku \& Humphreys, Brendan (2020),'Post-Soviet Russian culture. Anomy, desecularization and the conservative turn." - Russian Modernization: A New Paradigm (Studies in Contemporary Russia). Abingdon: Routledge, 174-258.

Knorre, Boris and Aleksei Zygmont (2019),"Militant Piety” in 21st-Century Orthodox Christianity: Return to Classical Traditions or Formation of a New Theology of War? - Religion, Dec, 2019.

Mitrofan (Badanin) (2013), Neugasimaja lampada "Kurska”, Murmansk: Ladan.

Mitrofan (Badanin) (2020), Tajna velikoi voiny, Murmansk: Ladan.

O svjatosti (1995), = O svjatosti ratnogo služenija. Yleisvenäläisessä kansankokouksessa hyväksytty asiakirja. https://vrns.ru/documents/55/1269. Katsottu 17.11.2020.

Palomäki, Janne (2020), "Suomalaisten joukkohautojen paljastajan piti päästä vapaaksi pian - sai liki kymmenen vuoden lisätuomion”. - Iltalehti, 29.9.2020.

Položenije (2013), Položenije o vojennom duhovenstve Russkoi Pravoslavnoi Tserkvi v Rossiiskoi Federatsii [Ohjeet ortodoksisen kirkon sotilaspapistosta Venäjän federaatiossa ] Patriarkan kotisivu. http://www.patriarchia.ru/db/text/3481010.html. Katsottu 17.11.2020.

Pravda o religii v Rossii (1943), Moskova: Izdatelstvo Moskovskoi Patriarhii. 
Riccardi-Swartz, Sarah (2020), Panel presentation 'Amerika Prekrasnaya: Of Guns, God, and Vodka' by Sarah Riccardi-Swartz, Conference on Global Orthodoxy, Institute of Eastern Christian Studies and the Radboud University, Oct 2, 2020, www.youtube.com/watch?v=ugPMteAZ3BE

Sartorti, Rosalinde (1995),"On the Making of Heroes, Heroines and Saints”. - Culture and Entertainment in Wartime Russia. Ed. by Richard Stites. Bloomington: Indiana University Press. Suslov, Mihail (ed.) (2016), Digital Orthodoxy in the Post-Soviet World. The Russian Orthodox Church and Web 2.0. Stuttgart: Ibidem.

Ševkunov, Tihon, Arhimandrit (2011), "Nesvjatyje svjatyje” i drugije rasskazy. Moskova: Izd-vo Sretenskogo monastyrja.

Ševkunov, Tihon (2016), Arkielämän pyhiä ynnä muita kertomuksia. [Suom. Irmeli Talasjoki] Lammi: Athos-Säätiö [Kaikkien Athosvuoren Pyhien Perintösäätiö].

Zhurzhenko, Tatiana (2020), "Toisen maailmansodan muisto venäläisessä provinssimediassa (Novgorod ja Murmansk)". - Sandarmohista Skolkovoon - historiapolitiikan pitkä varjo. Toim. Kaarina Aitamurto, Elina Kahla ja Jussi Lassila. Helsinki: Into.

Zobern, Vladimir (toim.) (2014), 70-letiju Velikoj pobedy posvjaštšajetsja: Bog i pobeda. Verujuštšije v velikih vojnah za Rossiju. Moskova: Eksmo. 